\title{
A Pooled Analysis Reporting the Efficacy and Safety of Secukinumab in Male and Female Patients with Ankylosing Spondylitis
}

\author{
Irene van der Horst-Bruinsma (D) - Corinne Miceli-Richard • \\ Juergen Braun · Helena Marzo-Ortega · Karel Pavelka • \\ Alan J. Kivitz · Atul Deodhar - Weibin Bao · Brian Porter • \\ Effie Pournara
}

Received: August 11, 2021 / Accepted: September 22, 2021 / Published online: October 7, 2021

(C) The Author(s) 2021

\section{ABSTRACT}

Introduction: Despite of higher disease burden, lower efficacy to biologics has been reported in female compared to male patients with ankylosing spondylitis (AS). The aim of this study was to evaluate the efficacy and safety of secukinumab by sex in patients with active AS from five phase 3 studies (MEASURE 1-5) through 52 weeks.

Methods: Baseline demographics, disease characteristics and efficacy outcomes at Weeks 16 and 52 were summarized for males versus

Supplementary Information The online version contains supplementary material available at https:// doi.org/10.1007/s40744-021-00380-2.

I. van der Horst-Bruinsma $(\square)$

Department of Rheumatology, ZH0D53, Amsterdam UMC/VU University Medical Centre, De Boelelaan

1117, 1081 HV Amsterdam, The Netherlands

e-mail: ie.vanderhorst@amsterdamumc.nl

C. Miceli-Richard

Université de Paris, Hôpital Cochin-Assistance

Publique-Hôpitaux de Paris, Paris, France

J. Braun

Rheumazentrum Ruhrgebiet, Ruhr-University

Bochum, Herne, Germany

H. Marzo-Ortega

NIHR Leeds Biomedical Research Centre, Leeds Teaching Hospitals Trust and Leeds Institute of Rheumatic and Musculoskeletal Medicine, University of Leeds, Leeds, UK females. Baseline predictor analysis used multivariable logistic regression for binary outcome measures or generalized linear model for continuous outcome measures to assess the impact of sex as one of the independent variables on selected efficacy outcomes at Week 52.

Results: Overall, 1031 males and 396 females were included in this analysis. Smoking status, hs-CRP, prior exposure to TNF inhibitors, BASMI occiput-to-wall and tragus-to-wall distance $(\mathrm{cm})$ were higher in males, whereas MASES was higher in females. Efficacy outcomes i.e., ASAS40 responses and BASDAI change from baseline at Weeks 16 and 52 were generally comparable between males and females. Response rates were found to be significantly higher in male patients when compared with

K. Pavelka

Institute of Rheumatology and Department of Rheumatology, 1st Faculty of Medicine, Charles University, Prague, Czech Republic

A. J. Kivitz

Altoona Center for Clinical Research, Duncansville, PA, USA

A. Deodhar

Oregon Health and Science University, Portland, OR, USA

W. Bao $\cdot$ B. Porter

Novartis Pharmaceuticals Corporation, East

Hanover, NJ, USA

E. Pournara

Novartis Pharma AG, Basel, Switzerland 
female patients only for ASDAS-CRP inactive disease (ID) at Week 52.

Conclusion: Comparable efficacy and safety outcomes were observed between male and female patients with active AS treated with secukinumab over 52 weeks. Further, sex was not an independent predictor of treatment response to secukinumab as assessed by ASAS40 responder rates and BASDAI change from baseline; association of ASDAS-CRP ID responder rates with sex warrants further exploration.

Trial registration: ClinicalTrials.gov; NCT01358175, NCT01649375, NCT02008916, NCT02159053, and NCT02896127.

Keywords: Ankylosing Interleukins; Sex; Biologics; Axial spondyloarthritis; Secukinumab; DMARDs; TNF inhibitors; Quality of life; Spondyloarthropathies

\section{Key Summary Points}

\section{Why carry out this study?}

The relative efficacy of the treatment of AS may differ between males and females, hence a better understanding of the sexattributable differences in response to biologic therapy is important.

This is the first post hoc analysis from a large, pooled dataset of patients with AS, reporting the efficacy and safety of an IL17 inhibitor by sex.

\section{What was learned from the study?}

High retention rates for both males and females were observed in this pooled dataset in contrast to previous studies with TNF inhibitors.

Secukinumab demonstrated comparable improvements in the assessed outcome measures across males and females through Week 52, except for ASDAS-CRP ID response rates.

\section{INTRODUCTION}

Ankylosing spondylitis (AS) is a chronic inflammatory disease of the axial skeleton and the sacroiliac joints $[1,2]$, historically seen as a predominantly male condition [3]. However, a steady decline in the male-female ratio has been reported among patients with AS, with increasing rates of diagnosis among women over 36 years (1980-2016) [4]. Recent studies have shown that female patients with AS report higher disease activity and functional impairment [5] with a reduced quality of life [6] and are likely to have higher disease burden than males [7-9]. In terms of AS phenotype, notable differences have been reported between male and female patients [10]; males present with more severe spinal radiographic changes [11] and less peripheral arthritis [12, 13].

It is generally recognized that the relative efficacy of the treatment of AS may differ between males and females, hence a better understanding of the sex-attributable differences in response to biologic therapy is important. However, data on the variability of treatment response to biologics with respect to sex in AS are limited. Previous analysis after tumor necrosis factor inhibitors (TNFi) suggest that efficacy may be lower in females than males even when similar disease burden is seen between the groups $[9,13]$. In addition, the treatment retention rate was markedly lower for female patients treated with TNFi compared to males [9].

Secukinumab, an interleukin (IL)-17A inhibitor, has demonstrated sustained improvement in the signs and symptoms of active AS in the MEASURE clinical trial program $[5,6,12,14,15]$. The impact of sex on the efficacy of secukinumab has not been thoroughly evaluated and although comparative effectiveness in the real-world setting between TNFi and secukinumab has been previously reported, stratification by sex was not investigated further $[16,17]$. In this post hoc analysis, we report efficacy and safety data pooled from five phase 3 MEASURE studies with respect to sex in patients with active AS treated with secukinumab through 52 weeks. 


\section{METHODS}

\section{Study design and patients}

Pooled data from MEASURE 1 (NCT01358175), MEASURE 2 (NCT01649375), MEASURE 3 (NCT02008916), MEASURE 4 (NCT02159053), and MEASURE 5 (NCT02896127) studies in patients with active AS were analyzed. The design, eligibility criteria, methodology and statistical analysis of these individual studies have been published elsewhere $[5,6,12,14,15]$. Briefly, patients aged $\geq 18$ years diagnosed with AS, fulfilling the modified New York criteria, with a Bath Ankylosing Spondylitis Disease Activity Index (BASDAI) score $\geq 4$ (on a $0-10$ scale) and spinal pain score $\geq 40 \mathrm{~mm}$ (on a 0-100 $\mathrm{mm}$ visual analogue scale), despite treatment with the maximum tolerated dose of NSAIDs, were included in these studies.

Key exclusion criteria were total spinal ankylosis, evidence of infection or cancer on chest radiography, active systemic infection within 2 weeks prior to randomization and previous treatment with cell-depleting therapies or biological agents other than TNFi agents. A flowchart of the key inclusion and exclusion criteria of MEASURE 1, 2, 3, 4, and 5 studies is presented in online Supplementary Figure S1.

In MEASURE 1 and MEASURE 3, patients were randomized to receive intravenous (i.v.) secukinumab $10 \mathrm{mg} / \mathrm{kg}$ at baseline and Weeks 2 and 4 , followed by subcutaneous (s.c.) secukinumab 150 or $75 \mathrm{mg}$ (MEASURE 1) or s.c. secukinumab 300 or $150 \mathrm{mg}$ (MEASURE 3) every 4 weeks $(\mathrm{q} 4 \mathrm{w})$ starting at Week 8 or matched placebo [12]. In MEASURE 2 and MEASURE 5, patients were randomized to receive s.c. secukinumab 75 or $150 \mathrm{mg}$ (MEASURE 2) or $150 \mathrm{mg}$ (MEASURE 5) at baseline, Weeks 1, 2 and 3 and $\mathrm{q} 4 \mathrm{w}$ starting at Week 4 or matched placebo $[6,12]$. In MEASURE 4, patients were randomized to receive s.c. secukinumab $150 \mathrm{mg}$ with loading doses (150 mg LD), without loading doses (150 mg no load), or placebo at baseline, Weeks 1, 2, and 3 and every 4 weeks starting at Week $4[14,15]$. Based on the clinical response, placebo-treated patients were switched to receive secukinumab at Week 16 or 24 in
MEASURE 1 study, whereas all patients receiving placebo in MEASURE 2, 3, 4, and 5 studies were switched to receive secukinumab at Week 16.

Efficacy results at Week 16 are presented for the following treatment groups: (a) secukinumab $300 \mathrm{mg}$ i.v. LD (secukinumab $300 \mathrm{mg}$ i.v. LD followed by secukinumab $300 \mathrm{mg}$ s.c.); (b) secukinumab $150 \mathrm{mg}$ i.v. LD (secukinumab $150 \mathrm{mg}$ i.v. LD followed by secukinumab $150 \mathrm{mg}$ s.c.); (c) secukinumab $150 \mathrm{mg}$ s.c. LD (secukinumab $150 \mathrm{mg}$ s.c. LD followed by secukinumab $150 \mathrm{mg}$ s.c.); (d) secukinumab $150 \mathrm{mg}$ no load (secukinumab $150 \mathrm{mg}$ s.c. no load followed by secukinumab $150 \mathrm{mg}$ s.c,) and (e) placebo. At Week 52, efficacy results are presented for the following groups: (i) Any secukinumab $300 \mathrm{mg}$ (secukinumab $300 \mathrm{mg}$ i.v. LD) and (ii) Any secukinumab $150 \mathrm{mg}$ (secukinumab $150 \mathrm{mg}$ i.v. LD, $150 \mathrm{mg}$ i.v. no-load, $150 \mathrm{mg}$ s.c. LD).

All study protocols and its amendments were reviewed and approved by the independent ethics committee or institutional review board for each participating center. The study was conducted according to the International Council for Harmonization (ICH) E6 Guideline for Good Clinical Practice (GCP) that has its origin in the Declaration of Helsinki. Written informed consent was obtained from all enrolled patients. Data were collected in accordance with the GCP guidelines by the study investigators and analyzed by the sponsor.

\section{Assessments}

This analysis assessed by sex included proportion of patients achieving Assessment of SpondyloArthritis international Society (ASAS)20, ASAS40, AS Disease Activity Score C-reactive Protein (CRP)-Inactive Disease (ASDAS-CRP ID), ASDAS-Clinically Important Improvement (CII) responses and the mean change from baseline in BASDAI, Bath Ankylosing Spondylitis Metrology Index (BASMI), Bath Ankylosing Spondylitis Functional Index (BASFI), Short Form (36)-Physical Component Summary (SF-36 PCS), Functional Assessment of Chronic Illness Therapy-Fatigue (FACIT- 
Fatigue) scores with secukinumab (up to Week 52) and placebo (up to Week 16). Baseline predictor analysis was also conducted to assess the impact of sex at Week 52 on the proportions of ASAS40 and ASDAS-CRP ID responders and the mean changes in BASDAI score from baseline. Overall safety and tolerability data were pooled by sex.

\section{Statistical Analyses}

Descriptive efficacy summaries are based on data as observed at Weeks 16 and 52 and are presented by treatment group (secukinumab or placebo) assigned at randomization.

In the baseline predictor analyses, univariate logistic regression analyses were first conducted to select potential baseline predictors. All the variables with $P$ values $<0.20$ from the univariate analyses were included in the multivariable logistic regression or generalized linear model (GLM) for further selection. Only those variables with $P$ values $<0.05$ were retained in the final models. Treatment group and sex, as a mandatory factor of primary interest, were included in the final models. To assess the impact of sex in 'any secukinumab' group as an independent variable on the binary efficacy outcomes of ASAS40 and ASDAS-CRP ID, a multivariate logistic regression analysis was performed. To assess the impact of sex on the continuous efficacy outcome of BASDAI change from baseline to Week 52, a GLM was used.

Pooled safety analyses by sex included all patients who received at least one dose of secukinumab.

\section{RESULTS}

\section{Baseline demographics and disease characteristics}

In total, 1031 male and 396 female patients with active AS who received secukinumab (males [ $n=642]$; females $[n=243]$ ) or placebo (males [ $n=389]$; females $[n=153]$ ) from MEASURE 1-5 studies, were included in this analysis. A total of 590 (91.9\%) males and 211 (86.8\%) females completed 52 weeks of secukinumab treatment, with a total mean (SD) exposure of 112.5 (73.2) weeks in males and 128.8 (80.1) weeks in females. The rates of discontinuation were slightly higher in females (12.3\%) vs. males $(8.4 \%)$ in 'any secukinumab' group with major reasons for discontinuation of the secukinumab treatment in the females being adverse events $(4.5 \%)$ followed by lack of efficacy $(4.1 \%)$.

Demographic and baseline disease characteristics by sex were reported in Table 1 . Smoking status, high sensitivity C-reactive protein (hs-CRP), prior TNFi exposure, BASMI occiputto-wall distance, BASMI tragus-to-wall distance were all higher in males and Maastricht Ankylosing Spondylitis Enthesitis Score (MASES) was higher in females. In particular, a significantly higher proportion of male patients were TNFinaïve $(P=0.0026)$ and current smokers $(P<0.0001)$ than female patients. The hs-CRP levels, mean BASMI score (Linear), BASMI occiput-to-wall distance and BASMI tragus-to-wall distance were significantly higher in males $(P<0.0001)$; on the contrary, mean MASES score was significantly higher in females $(P<0.0001)$. The mean baseline BASDAI score was $\sim 7$ across 'Any secukinumab' group and placebo groups in both males and females.

\section{Efficacy by sex}

A comparable proportion of male versus female patients achieved an ASAS40 response at Week 16 across all secukinumab groups, which was sustained or further improved at Week 52 in males ('Any secukinumab' $300 \mathrm{mg}$ : 61.7\% and $150 \mathrm{mg}$ : 60.0\%) versus females ('Any secukinumab' $300 \mathrm{mg}: 68.4 \%$ and $150 \mathrm{mg}: 56.2 \%$ at Week 52) (Fig. 1A). A similar trend in the decrease of mean BASDAI scores was observed in male versus female patients at Week 16 across all secukinumab groups, which was improved at Week 52: 'Any secukinumab' $300 \mathrm{mg}$ (males: - 3.6 vs. females: - 3.7) and 'Any secukinumab' $150 \mathrm{mg}$ groups (males: -3.4 vs. females: - 3.5) (Fig. 1B). Other efficacy parameters including ASAS20, ASDAS-CRP ID and ASDAS-CRP CII responses, as well as mean 
Table 1 Demographic and baseline disease characteristics by sex

\begin{tabular}{|c|c|c|c|c|c|}
\hline \multirow[t]{2}{*}{ Characteristic mean (SD) unless specified otherwise } & \multicolumn{2}{|c|}{ Any secukinumab } & \multicolumn{2}{|l|}{ Placebo } & \multirow[t]{2}{*}{$P$ value* } \\
\hline & $\begin{array}{l}\text { Male } \\
N=642\end{array}$ & $\begin{array}{l}\text { Female } \\
N=243\end{array}$ & $\begin{array}{l}\text { Male } \\
N=389\end{array}$ & $\begin{array}{l}\text { Female } \\
N=153\end{array}$ & \\
\hline Age (years) & $38.9(11.4)$ & $41.6(12.2)$ & $39.1(12.4)$ & $43.5(12.6)$ & $<0.0001$ \\
\hline Weight $(\mathrm{kg})$ & $79.7(18.4)$ & $70.8(17.8)$ & $78.6(15.1)$ & $71.4(16.5)$ & $<0.0001$ \\
\hline BMI $\left(\mathrm{kg} / \mathrm{m}^{2}\right)$ & $26.2(5.5)$ & $26.6(6.3)$ & $25.9(4.5)$ & $27.0(6.1)$ & 0.0307 \\
\hline Current smoking (yes), $n(\%)$ & $239(37.2)$ & $42(17.3)$ & $148(38.0)$ & $33(21.6)$ & $<0.0001$ \\
\hline Time since first diagnosis of AS (years) & $6.5(7.7)$ & $6.0(7.6)$ & $6.8(8.2)$ & $6.2(7.5)$ & 0.2322 \\
\hline hs-CRP (mg/L) & $18.3(28.2)$ & $10.7(18.1)$ & $17.9(22.9)$ & $10.0(14.8)$ & $<0.0001$ \\
\hline TNFi naïve, $n(\%)$ & $489(76.2)$ & $170(70.0)$ & $297(76.3)$ & $101(66.0)$ & 0.0026 \\
\hline MASES & $2.4(3.1)$ & $4.6(3.8)$ & $2.3(3.0)$ & $4.9(3.9)$ & $<0.0001$ \\
\hline ASDAS-CRP & $3.81(0.8)$ & $3.6(0.9)$ & $3.83(0.9)$ & $3.65(0.8)$ & $<0.0001$ \\
\hline BASDAI & $6.7(1.4)$ & $7.1(1.4)$ & $6.7(1.3)$ & $7.1(1.4)$ & $<0.0001$ \\
\hline BASMI linear $(\mathrm{cm})$ & $3.9(1.8)$ & $3.3(1.4)$ & $3.9(1.7)$ & $3.5(1.5)$ & $<0.0001$ \\
\hline BASMI occiput-to-wall distance $(\mathrm{cm})$ & $4.8(6.0)$ & $2.6(4.2)$ & $5.3(7.3)$ & $2.5(4.0)$ & $<0.0001$ \\
\hline BASMI tragus-to-wall distance $(\mathrm{cm})$ & $14.7(5.2)$ & $12.1(2.9)$ & $15.2(5.3)$ & $12.5(3.3)$ & $<0.0001$ \\
\hline BASFI & $6.1(2.0)$ & $6.3(2.1)$ & $6.1(1.9)$ & $6.1(2.2)$ & 0.3065 \\
\hline
\end{tabular}

ASDAS Ankylosing Spondylitis Disease Activity Score, BASDAI Bath Ankylosing Spondylitis Disease Activity Index, BASFI Bath Ankylosing Spondylitis Functional Index, BASMI Bath Ankylosing Spondylitis Metrology Index, hs-CRP high sensitivity C-reactive protein, $P B O$ placebo, $S D$ standard deviation, $T N F i$ tumor necrosis factor inhibitor

change from baseline in BASFI, BASMI, SF-36 PCS, and FACIT-Fatigue at Weeks 16 and 52 are shown in Table 2.

There was no significant impact of sex as an independent predictor of treatment response to 'Any secukinumab' group on ASAS40 response rates $(\mathrm{OR}, 1.30 ; P=0.10)$ or the change from baseline in BASDAI score (OR, $-0.10 ; P=0.48)$ at Week 52. However, a significant impact of sex on treatment response to 'Any secukinumab' group was observed for ASDAS-CRP ID in male patients $(\mathrm{OR}, 1.70 ; P=0.002)$ when compared with female patients at Week 52 (Table 3).

\section{Safety}

During the entire safety reporting period, treatment-emergent adverse events were reported in the 'Any secukinumab' group for 550 males (85.8\%) and 220 females $(90.5 \%)$ (Table 4). The most frequent treatment-emergent $\mathrm{AE}$ during the entire safety period was nasopharyngitis in both males and females. The proportion of male patients with non-fatal SAEs was comparable to that of female patients (11.5\% vs. $9.9 \%$, respectively). A higher proportion of female patients experienced AEs that led to treatment discontinuation, as compared to male patients $(12.3 \%$ and $8.4 \%$, respectively) (Table 4). There were four male patients who reported ulcerative colitis $v s$. one female patient; Crohn's disease was reported in one male patient, which led to study discontinuation. Candida infection was reported in one female patient, which was resolved and, was not considered to be related to study medication, and did not lead to study discontinuation. 


\section{DISCUSSION}

This is the first post hoc analysis reporting efficacy and safety by sex from a large, pooled dataset of 1427 patients with active AS from five pooled randomized clinical trials of secukinumab $[5,6,12,14,15]$. Although there is a gap of knowledge on the performance of different efficacy outcome measures according to sex, secukinumab generally demonstrated comparable treatment responses for male and female AS patients both at Weeks 16 and 52 . Furthermore, although for some outcome measures, females at Week 16 were behind males in terms of response rates ( $37.5 \%$ vs. $46.9 \%)$, they

A
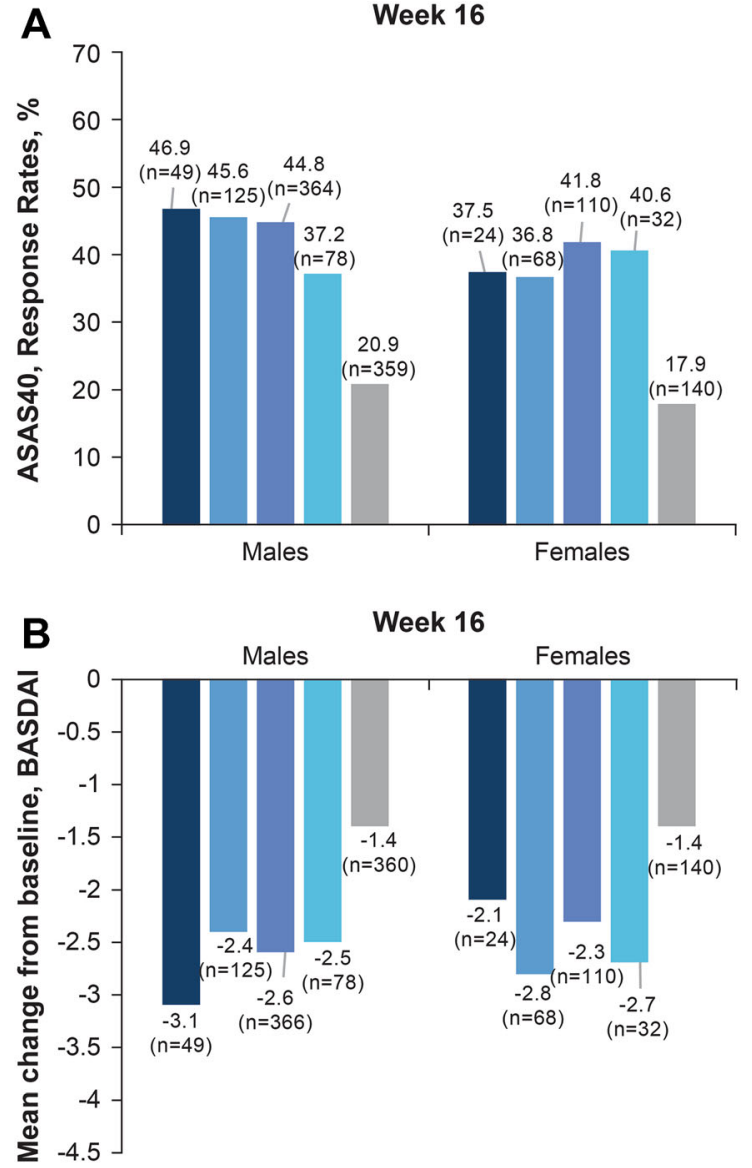

$\square 300 \mathrm{mg}$ IV Load $\square 150 \mathrm{mg}$ IV Load $\square 150 \mathrm{mg} \mathrm{sc} \mathrm{Load} \square 150 \mathrm{mg}$ no Load $\square$ Placebo reached and even outperformed male patients by Week 52 (68.4\% vs. 61.7\%). The observed differences in efficacy after 16 weeks of treatment were no longer evident at Week 52, suggesting that longer term follow up might be needed to assess the full magnitude of response in female patients This analysis also demonstrated a high retention rate for different doses of secukinumab at Week 52 for both males and females (91.9\% vs. $86.8 \%$, respectively), with even higher mean treatment exposure for female patients (128.8 weeks vs. 112.5 weeks).

The differences in immune responses, sex hormones, and genetic predisposition might contribute to variable disease manifestations and therapeutic response to biologics in men
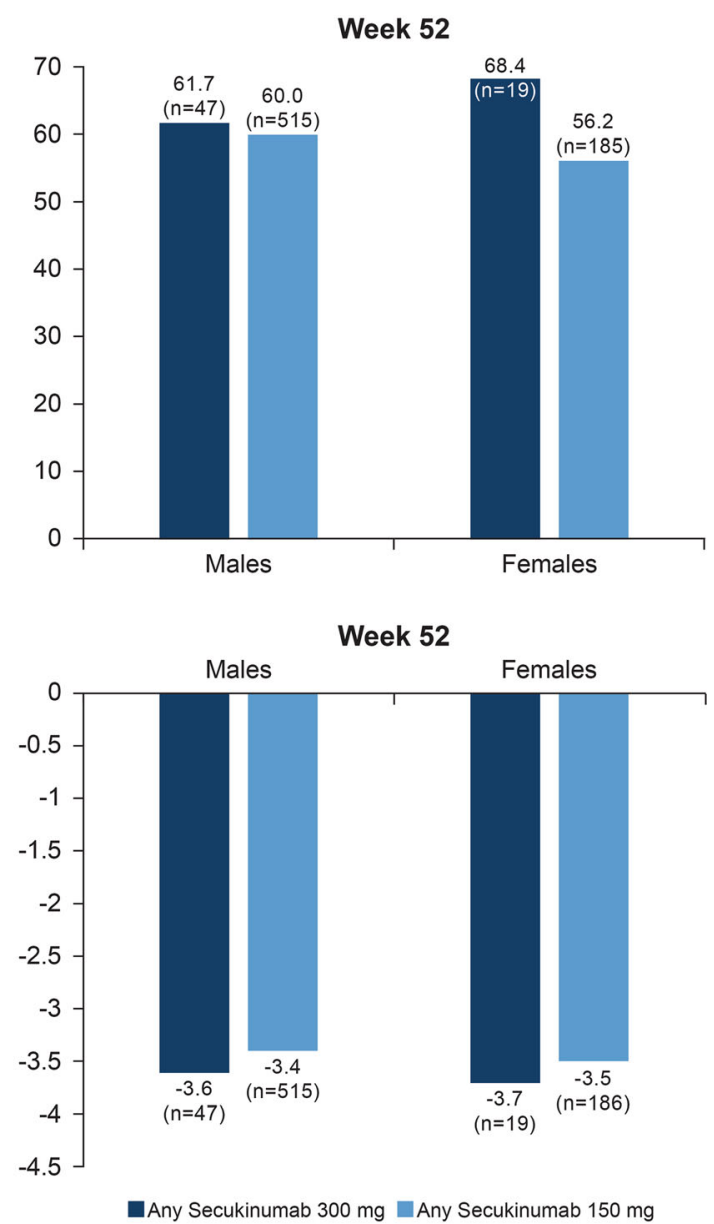

SpondyloArthritis international Society, BASDAI Bath Ankylosing Spondylitis Disease Activity Index, $n$ total number of patients evaluated in the treatment group 
Table 2 Summary of efficacy responses by sex

\begin{tabular}{|c|c|c|c|c|c|c|c|}
\hline \multirow[t]{2}{*}{ Variable, } & \multirow[t]{2}{*}{ Week } & \multicolumn{2}{|c|}{$\begin{array}{l}\text { Any secukinumab } \\
300 \mathrm{mg}\end{array}$} & \multicolumn{2}{|c|}{$\begin{array}{l}\text { Any secukinumab } \\
150 \mathrm{mg}\end{array}$} & \multicolumn{2}{|l|}{ Placebo } \\
\hline & & $\begin{array}{l}\text { Male } \\
(N=50)\end{array}$ & $\begin{array}{l}\text { Female } \\
(N=26)\end{array}$ & $\begin{array}{l}\text { Male } \\
(N=592)\end{array}$ & $\begin{array}{l}\text { Female } \\
(N=217)\end{array}$ & $\begin{array}{l}\text { Male } \\
(N=389)\end{array}$ & $\begin{array}{l}\text { Female } \\
(N=153)\end{array}$ \\
\hline \multirow[t]{2}{*}{ ASAS20, $\%(n)$} & 16 & $69.4(49)$ & $50(24)$ & $62.6(567)$ & $62.9(210)$ & $39.8(359)$ & $37.9(140)$ \\
\hline & 52 & $83.0(47)$ & $73.7(19)$ & $75.7(515)$ & $74.6(185)$ & - & - \\
\hline \multirow{2}{*}{$\begin{array}{l}\text { ASDAS-CRP inactive disease, } \\
\%(n)\end{array}$} & 16 & $20.4(49)$ & $20.8(24)$ & $15.5(567)$ & $14.9(208)$ & $4.2(360)$ & $2.2(139)$ \\
\hline & 52 & $25.5(47)$ & $31.6(19)$ & $25.2(515)$ & $22.6(186)$ & - & - \\
\hline \multirow[t]{2}{*}{ ASDAS-CRP CII*, $\%(n)$} & 16 & $65.3(49)$ & $45.8(24)$ & $60.1(567)$ & $48.6(208)$ & $23.4(359)$ & $21.6(139)$ \\
\hline & 52 & $68.1(47)$ & $63.2(19)$ & $74.2(515)$ & $62.9(186)$ & - & - \\
\hline \multirow[t]{2}{*}{$\begin{array}{l}\text { BASFI, mean change from } \\
\text { baseline }(\mathrm{SD}) / n\end{array}$} & 16 & $\begin{array}{l}-2.7 \\
(2.6) / \\
49\end{array}$ & $\begin{aligned}- & 2.2 \\
& (3.1) / 24\end{aligned}$ & $\begin{array}{l}-2.1 \\
(2.3) / \\
569\end{array}$ & $\begin{array}{r}-2.1(2.4) / \\
210\end{array}$ & $\begin{array}{c}-1.1 \\
(2.2) / \\
360\end{array}$ & $\begin{array}{l}-0.8(2.2) / \\
140\end{array}$ \\
\hline & 52 & $\begin{array}{l}-3.1 \\
(2.4) / \\
47\end{array}$ & $\begin{aligned}- & 3.6 \\
& (2.6) / 19\end{aligned}$ & $\begin{array}{l}-2.9 \\
(2.4) / \\
515\end{array}$ & $\begin{array}{l}-2.9(2.7) / \\
186\end{array}$ & - & - \\
\hline \multirow[t]{2}{*}{$\begin{array}{l}\text { BASMI, mean change from } \\
\text { baseline }(\mathrm{SD}) / n\end{array}$} & 16 & $\begin{array}{c}-0.4 \\
(0.8) / \\
49\end{array}$ & $\begin{aligned}- & 0.3 \\
& (0.7) / 25\end{aligned}$ & $\begin{array}{c}-0.6 \\
(0.8) / \\
557\end{array}$ & $\begin{array}{l}-0.3(0.8) / \\
207\end{array}$ & $\begin{array}{c}-0.3 \\
(0.8) / \\
354\end{array}$ & $\begin{array}{l}-0.2(0.9) / \\
136\end{array}$ \\
\hline & 52 & $\begin{array}{c}-0.5 \\
(0.9) / \\
48\end{array}$ & $\begin{array}{r}-0.6 \\
(1.0) / 19\end{array}$ & $\begin{array}{c}-0.8 \\
(0.9) / \\
505\end{array}$ & $\begin{array}{l}-0.6(0.9) / \\
183\end{array}$ & - & - \\
\hline \multirow[t]{2}{*}{$\begin{array}{l}\text { SF-36 PCS, mean change from } \\
\text { baseline }(\mathrm{SD}) / n\end{array}$} & 16 & $\mathrm{NA}^{\dagger}$ & $\mathrm{NA}^{\dagger}$ & $\begin{array}{c}6.8(7.0) / \\
531\end{array}$ & $\begin{array}{c}7.0(7.8) / \\
185\end{array}$ & $\begin{array}{l}3.5(7.0) / \\
330\end{array}$ & $\begin{array}{l}3.1(7.1) / \\
109\end{array}$ \\
\hline & 52 & $\mathrm{NA}^{\dagger}$ & $\mathrm{NA}^{\dagger}$ & $\begin{array}{l}8.6(7.7) / \\
487\end{array}$ & $\begin{array}{l}9.3(8.5) / \\
172\end{array}$ & - & - \\
\hline \multirow[t]{2}{*}{$\begin{array}{l}\text { FACIT-F, mean change from } \\
\text { baseline }(\mathrm{SD}) / n\end{array}$} & 16 & $\mathrm{NA}^{\dagger}$ & $\mathrm{NA}^{\dagger}$ & $\begin{array}{c}7.7(9.3) / \\
289\end{array}$ & $\begin{array}{l}9.1(11.8) / \\
132\end{array}$ & $\begin{array}{l}4.7(9.4) / \\
201\end{array}$ & $\begin{array}{l}4.6(10.5) / \\
90\end{array}$ \\
\hline & 52 & $\mathrm{NA}^{\dagger}$ & $\mathrm{NA}^{\dagger}$ & $\begin{array}{c}9.8(10.4) / \\
265\end{array}$ & $\begin{array}{l}12.0(12.0) / \\
123\end{array}$ & - & - \\
\hline
\end{tabular}

Data is presented as observed

$N$ total number of patients in the group; $n$ total number of evaluable patients in the treatment group

$A S A S$ Assessments of SpondyloArthritis international Society, ASDAS Ankylosing Spondylitis Disease Activity Score, BASFI Bath Ankylosing Spondylitis Functional Index, BASMI Bath Ankylosing Spondylitis Metrology Index, CII clinically important improvement, CRP C-reactive protein, SF-36 PCS Short Form-36 Physical Component Summary, FACIT-F Functional Assessment of Chronic Illness Therapy-Fatigue, $P B O$ placebo, $S D$ standard deviation

*ASDAS-CRP CII is defined as a change $\geq 1.1$ units

$\dagger$ NA, outcomes were not assessed in MEASURE 3 trial, which was the only trial to include secukinumab 300 mg dose 
Table 3 Impact of sex on ASAS40, ASDAS-CRP ID, and BASDAI at week 52

\begin{tabular}{|c|c|c|c|c|c|c|}
\hline \multirow[t]{3}{*}{ Predictor } & \multicolumn{6}{|l|}{ Variables } \\
\hline & \multicolumn{2}{|l|}{$\overline{\text { ASAS } 40^{a}}$} & \multicolumn{2}{|c|}{ ASDAS-CRP ID ${ }^{a}$} & \multicolumn{2}{|l|}{ BASDAI $^{b}$} \\
\hline & $\begin{array}{l}\text { Odds ratio } \\
(95 \% \mathrm{CI})\end{array}$ & $P$ value & $\begin{array}{l}\text { Odds ratio } \\
(95 \% \mathrm{CI})\end{array}$ & $P$ value & $\begin{array}{l}\text { Treatment effect } \\
(95 \% \mathrm{CI})\end{array}$ & $P$ value \\
\hline Baseline ASDAS-CRP & NA & NA & $\begin{array}{l}0.66(0.56 \\
0.79)\end{array}$ & $<0.0001$ & NA & NA \\
\hline Baseline BASDAI & NA & NA & NA & NA & $0.54(0.45,0.63)$ & $<0.0001$ \\
\hline Sex (male vs. female) & $1.3(1.0,1.6)$ & 0.0992 & $1.7(1.2,2.4)$ & 0.0019 & $-0.1(-0.4,0.2)$ & 0.4824 \\
\hline Age (years) & $\begin{array}{c}0.98(0.97 \\
0.99)\end{array}$ & 0.0022 & - & - & $0.02(0.01,0.03)$ & 0.0004 \\
\hline $\begin{array}{l}\text { BMI }\left(<30 \mathrm{~kg} / \mathrm{m}^{2} \text { vs. }\right. \\
\left.\quad \geq 30 \mathrm{~kg} / \mathrm{m}^{2}\right)\end{array}$ & $1.4(1.0,1.8)$ & 0.0349 & $3.0(1.9,4.8)$ & $<0.0001$ & $\begin{array}{l}-0.4(-0.8 \\
-0.1)\end{array}$ & 0.0054 \\
\hline TNFi status (naïve vs. IR) & $1.6(1.2,2.0)$ & 0.0006 & $1.9(1.3,2.8)$ & 0.0004 & $\begin{array}{l}-0.4(-0.7 \\
-0.2)\end{array}$ & 0.0024 \\
\hline $\begin{array}{l}\text { hsCRP }(\geq 5 \mathrm{mg} / \mathrm{L} \text { vs. } \\
\quad<5 \mathrm{mg} / \mathrm{L})\end{array}$ & $1.7(1.3,2.1)$ & $<0.0001$ & - & - & $\begin{array}{l}-0.5(-0.8 \\
-0.2)\end{array}$ & 0.0002 \\
\hline Current smoker (no vs. yes) & $1.3(1.0,1.7)$ & 0.0240 & - & - & $-0.3(-0.5,0.0)$ & 0.0416 \\
\hline $\begin{array}{l}\text { BASMI-occiput- to-wall } \\
\text { distance }(\mathrm{cm})\end{array}$ & $\begin{array}{c}0.96(0.93 \\
0.98)\end{array}$ & 0.0002 & $\begin{array}{c}0.90(0.87 \\
0.94)\end{array}$ & $<0.0001$ & $0.10(0.05,0.14)$ & $<0.0001$ \\
\hline $\begin{array}{l}\text { BASMI-Tragus to wall } \\
\text { distance }(\mathrm{cm})\end{array}$ & - & - & - & - & $\begin{array}{l}-0.06(-0.11 \\
-0.01)\end{array}$ & 0.0198 \\
\hline
\end{tabular}

In the final models, except treatment and sex (which were included mandatorily), only those factors with $P$ values $<0.05$ were kept

ASAS Assessment of SpondyloArthritis international Society, ASDAS Ankylosing Spondylitis Disease Activity Score, BMI Body Mass Index, $C I$ confidence interval, $h s$ - $C R P$ high sensitivity C-reactive protein, $I R$ inadequate responders, $N A$ not applicable, - not selected in the final model, TNFi tumor necrosis factor inhibitor

a Analyses were done using multivariate logistic regression

b Analysis was done using generalized linear model

and women with AS. A study by Thaci et al. demonstrated distinct sexual dimorphism in the activation status of the immune system in AS in the Th17 axis; thus, sex-related differences in the clinical features of AS could be attributed to this sexual dimorphism [18]. Although not fully established, few studies have shown that sex hormones could also affect treatment responses to biologics in AS [19-22]. Also, allelic frequencies of the ANKH-gene, which specifically encodes for a progressive ankylosing protein, and tissue non-specific alkaline phosphatase haplotypes differ between males and females with AS [3].

Although sex differences in terms of prevalence and AS phenotypes are observed across many studies [23], it has been challenging to investigate sex differences in the efficacy of TNFi in the randomized controlled setting as the number of enrolled female patients was low, the analyses were usually not stratified by sex, and most of these trials were not designed or powered to demonstrate treatment responses by sex $[24,25]$. Previous pooled efficacy analyses of TNFi treatment reported sex differences $[3,8,9]$ 
Table 4 Treatment emergent AEs during the entire treatment period

\begin{tabular}{|c|c|c|c|}
\hline Parameters & Males $(N=641)$ & Females $(N=243)$ & Total $(N=884)$ \\
\hline Exposure (weeks), mean (SD) & $112.5(73.2)$ & $128.8(80.1)$ & $117.0(75.5)$ \\
\hline Any AEs, $n(\%)$ & $550(85.8)$ & $220(90.5)$ & $770(87.1)$ \\
\hline Serious AE, $n(\%)$ & $74(11.5)$ & $24(9.9)$ & $98(11.1)$ \\
\hline Discontinuation due to any $\mathrm{AE}, n(\%)$ & $28(4.4)$ & $14(5.8)$ & $42(4.8)$ \\
\hline \multicolumn{4}{|l|}{ Most common AEs, $n(\%)^{a}$} \\
\hline Nasopharyngitis & $135(21.1)$ & $62(25.5)$ & $197(22.3)$ \\
\hline Upper respiratory tract infection & $127(19.8)$ & $47(19.3)$ & $174(19.7)$ \\
\hline Diarrhoea & $61(9.5)$ & $28(11.5)$ & $89(10.1)$ \\
\hline Headache & $36(5.6)$ & $33(13.6)$ & $69(7.8)$ \\
\hline Back pain & $29(4.5)$ & $28(11.5)$ & $57(6.4)$ \\
\hline Bronchitis & $28(4.4)$ & $25(10.3)$ & $53(6.0)$ \\
\hline Influenza & $38(5.9)$ & $16(6.6)$ & $54(6.1)$ \\
\hline Arthralgia & $40(6.2)$ & $18(7.4)$ & $58(6.6)$ \\
\hline Ankylosing spondylitis & $34(5.3)$ & $18(7.4)$ & $52(5.9)$ \\
\hline Oropharyngeal pain & $33(5.1)$ & $20(8.2)$ & $53(6.0)$ \\
\hline Cough & $28(4.4)$ & $17(7.0)$ & $45(5.1)$ \\
\hline Pharyngitis & $30(4.7)$ & $20(8.2)$ & $50(5.7)$ \\
\hline Respiratory tract infection & $24(3.7)$ & $16(6.6)$ & $40(4.5)$ \\
\hline Hypertension & $31(4.8)$ & $15(6.2)$ & $46(5.2)$ \\
\hline \multicolumn{4}{|c|}{ AEs of special interest, $n$ (EAIR/100 patient years) } \\
\hline Candida infection & $0(0.0)$ & $1(0.2)$ & - \\
\hline Crohn's disease & $1(0.1)$ & $0(0.0)$ & - \\
\hline Colitis ulcerative & $4(0.3)$ & $1(0.2)$ & - \\
\hline Malignant melanoma & $1(0.1)$ & $0(0.0)$ & - \\
\hline
\end{tabular}

Events listed according to preferred term in the Medical Dictionary for Regulatory Activities (MedDRA) version 21.1, sorted in descending order of EAIR in the Any secukinumab 150 and $75 \mathrm{mg}$ group for the entire treatment period $A E$ adverse events, $E A I R$ exposure adjusted incidence rate, $N$ number of randomized patients, $n$ number of evaluable patients

${ }^{\text {a }}$ Seen in more than $5 \%$ of total patients randomized to secukinumab

with notably lower levels of therapeutic response and treatment adherence in female patients $[8,9,26-34]$. Even though the disease burden at baseline is comparable or worse in female compared to male patients, female patients with AS have demonstrated less efficacy from biologics as compared with male patients [35-37].

Prevalence of fibromyalgia is higher in female patients and has been suggested as a potential reason for reduced treatment responses to biologics in female patients with AS; 
however, this information might also lead to the misdiagnosis of cases of enthesitis for fibromyalgia [38]. In the present pooled analysis, although female patients had higher MASES score, ASAS40 response rates and change from baseline in BASDAI scores were comparable at Week 52, indicating good efficacy on enthesitis irrespective of sex. However, sex appears to have an impact on ASDAS-CRP ID, which is a higher hurdle efficacy endpoint and hence achieved by a small proportion of patients. As CRP levels are a predictor of response, higher CRP at baseline in male patients may have favored males in terms of response to secukinumab treatment as there is bigger window for normalization of CRP levels [39]. This may potentially compromise the clinical interpretation of this outcome measure in assessing the differential treatment effect of secukinumab in achieving disease remission.

The overall safety profile of secukinumab was consistent with previous reports similar across male and female patients [14, 18-20, 23].

\section{CONCLUSION}

In this pooled database of the five MEASURE studies, although some differences between the sexes were observed at Week 16, the sustained improvements through Week 52 across a wide range of efficacy outcomes in AS patients treated with secukinumab $300 \mathrm{mg}$ or $150 \mathrm{mg}$ were generally achieved irrespective of sex. Although sex was not an independent predictor of treatment response to secukinumab as assessed by ASAS40 responder rates and BASDAI change from baseline, the association of ASDAS-CRP ID responder rates with sex warrants further exploration. No differences were observed in the safety profile of secukinumab between male and female patients.

\section{ACKNOWLEDGEMENTS}

The authors thank the patients who participated in this study and the study investigators.
Funding. This study and the Rapid Service Fee was funded by Novartis Pharma AG, in accordance with Good Publication Practice (GPP3) guidelines (http://www.ismpp.org/ gpp3).

Medical Writing, Editorial, and Other Assistance. The authors thank John Gallagher, a medical consultant working with Novartis. Monisha Kasaraneni and Hemangi Rawal (Novartis, India) provided medical writing support for this manuscript under the guidance of all authors.

Authorship. All named authors meet the International Committee of Medical Journal Editors (ICMJE) criteria for authorship for this article, take responsibility for the integrity of the work as a whole, were involved in the drafting and critical review of the manuscript and approved the final version for submission. All authors agree to be accountable for all aspects of the work and attest to the accuracy and integrity of the work.

Helena Marzo-Ortega is supported by the National Institute for Health Research (NIHR) Leeds Biomedical Research Centre (LBRC). The views expressed are those of the authors and not necessarily those of the (UK) National Health Service (NHS), the NIHR, or the (UK) Department of Health.

Author Contributions. Substantial contributions to study conception and design: Irene van der Horst-Bruinsma, Brian Porter, Effie Pournara, Weibin Bao; Substantial contributions to acquisition of data: Irene van der HorstBruinsma, Corinne Miceli-Richard, Juergen Braun, Helena Marzo-Ortega, Karel Pavelka, Alan J Kivitz, Atul Deodhar; Substantial contributions to analysis and interpretation of data: Irene van der Horst-Bruinsma, Corinne MiceliRichard, Juergen Braun, Helena Marzo-Ortega, Karel Pavelka, Alan J Kivitz, Atul Deodhar, Weibin Bao, Brian Porter, Effie Pournara; Drafting the article or revising it critically for important intellectual content: Irene van der Horst-Bruinsma, Corinne Miceli-Richard, Juergen Braun, Helena Marzo-Ortega, Karel Pavelka, Alan J Kivitz, Atul Deodhar, Weibin Bao, Brian 
Porter, Effie Pournara; Final approval of the version of the article to be published: Irene van der Horst-Bruinsma, Corinne Miceli-Richard, Juergen Braun, Helena Marzo-Ortega, Karel Pavelka, Alan J Kivitz, Atul Deodhar, Weibin Bao, Brian Porter, Effie Pournara.

Disclosures. IvdHB has received research grants from AbbVie, Pfizer, MSD and UCB, and honoraria/speakers fee from Novartis, BMS, Lilly, AbbVie, MSD, Pfizer and UCB. CM-R reports grants from Novartis and is member of the national advisory board of rheumatology of Novartis. JB reports grant/research support from AbbVie, Amgen, BMS, Boehringer, Celgene, Celltrion, Centocor, Chugai, Medac, MSD, Mundipharma, Novartis, Pfizer, Roche, SanofiAventis and UCB; consultation fees from AbbVie, Amgen, BMS, Boehringer, Celgene, Celltrion, Centocor, Chugai, EBEWE Pharma, Medac, MSD, Mundipharma, Novartis, Pfizer, Roche, Sanofi-Aventis and UCB; and received speakers bureau fees from AbbVie, Amgen, BMS, Boehringer, Celgene, Celltrion, Centocor, Chugai, EBEWE Pharma, Medac, MSD, Mundipharma, Novartis, Pfizer, Roche, Sanofi-Aventis and UCB. RB reports research grants from AbbVie, MSD and Roche; consulting fees from AbbVie, Pfizer, Roche, Bristol-Myers, Janssen and MSD; and speakers bureau fees from AbbVie, Pfizer, Roche, Bristol-Myers, Janssen, MSD and Eli Lilly. HMO has received research grants from Janssen and Novartis, and honoraria/ speaker fess from AbbVie, Celgene, Janssen, Lilly, Novartis, Pfizer, Takeda and UCB. KP reports honoraria for lectures and consultations from companies: Pfizer, MSD, BMS, UCB, Amgen, Egis, Roche, AbbVie. AJ Kivitz reports shareholder of: Pfizer, Sanofi, Novartis, Amgen, GlaxoSmithKline, Gilead Sciences, Inc., Consultant fees from: AbbVie, Boehringer Ingelheim, Flexion, Janssen, Pfizer, Sanofi, Regeneron, SUN Pharma Advanced Research, Gilead Sciences, Inc., Speakers bureau: Celgene, GlaxoSmithKline, Eli Lilly, Merck, Novartis, Pfizer, Sanofi, Genzyme, Flexion, AbbVie, UCB. $\mathrm{AD}$ reports receiving honoraria for consulting or speaking for or research grants from AbbVie, Amgen, Boehringer Ingelheim, Celgene, Eli Lilly, Galapagos, GSK, Janssen, Novartis, Pfizer and UCB. WB is employee of Novartis. BP and EP are employees of Novartis and owns Novartis Stock.

Compliance with Ethics Guidelines. All study protocols and its amendments were reviewed and approved by the independent ethics committee or institutional review board for each participating center. The study was conducted according to the International Council for Harmonisation (ICH) E6 Guideline for Good Clinical Practice (GCP) that has its origin in the Declaration of Helsinki. Written informed consent was obtained from all enrolled patients. Data were collected in accordance with the GCP guidelines by the study investigators and analyzed by the sponsor.

Data Availability. The datasets generated and/or analyzed during the current study are not publicly available. Novartis is committed to sharing with qualified external researchers' access to patient-level data and supporting clinical documents from eligible studies. These requests are reviewed and approved based on scientific merit. All data provided are anonymized to respect the privacy of patients who have participated in the trial in line with applicable laws and regulations. The data may be requested from the corresponding author of the manuscript.

Open Access. This article is licensed under a Creative Commons Attribution-NonCommercial 4.0 International License, which permits any non-commercial use, sharing, adaptation, distribution and reproduction in any medium or format, as long as you give appropriate credit to the original author(s) and the source, provide a link to the Creative Commons licence, and indicate if changes were made. The images or other third party material in this article are included in the article's Creative Commons licence, unless indicated otherwise in a credit line to the material. If material is not included in the article's Creative Commons licence and your intended use is not permitted by statutory regulation or exceeds the permitted use, you will need to obtain permission directly from the copyright holder. To view a copy of this licence, 
visit http://creativecommons.org/licenses/by$\mathrm{nc} / 4.0 /$.

\section{REFERENCES}

1. Dougados M, Baeten D. Spondyloarthritis. Lancet (London, England). 2011;377(9783):2127-37.

2. Garg N, van den Bosch F, Deodhar A. The concept of spondyloarthritis: where are we now? Best Pract Res Clin Rheumatol. 2014;28(5):663-72.

3. Rusman $\mathrm{T}$, van Vollenhoven RF, van der HorstBruinsma IE. Gender differences in axial spondyloarthritis: women are not so lucky. Curr Rheumatol Rep. 2018;20(6):35.

4. Baumberger H, Khan M. SAT0417 Gradual progressive change to equal prevalence of ankylosing spondylitis among males and females in switzerland: data from the swiss ankylosing spondylitis society (SVMB). Ann Rheum Dis. 2017;76(Suppl 2): 929.

5. Marzo-Ortega H, Sieper J, Kivitz A, Blanco R, Cohen M, Delicha E-M, et al. Secukinumab provides sustained improvements in the signs and symptoms of active ankylosing spondylitis with high retention rate: 3-year results from the phase III trial, MEASURE 2. RMD Open. 2017;3(2): e000592.

6. Pavelka K, Kivitz A, Dokoupilova E, Blanco R, Maradiaga $M$, Tahir $H$, et al. Efficacy, safety, and tolerability of secukinumab in patients with active ankylosing spondylitis: A randomized, doubleblind phase 3 study, MEASURE 3. Arthritis Res Ther. 2017;19(1):285.

7. Haroon NN, Paterson JM, Li P, Haroon N. Increasing proportion of female patients with ankylosing spondylitis: a population-based study of trends in the incidence and prevalence of AS. BMJ Open. 2014;4(12): e006634.

8. Rusman T, Ten Wolde S, Euser SM, van der Ploeg T, van Hall $\mathrm{O}$, van der Horst-Bruinsma IE. Gender differences in retention rate of tumor necrosis factor alpha inhibitor treatment in ankylosing spondylitis: a retrospective cohort study in daily practice. Int J Rheum Dis. 2018;21(4):836-42.

9. van der Horst-Bruinsma IE, Zack DJ, Szumski A, Koenig AS. Female patients with ankylosing spondylitis: analysis of the impact of gender across treatment studies. Ann Rheum Dis. 2013;72(7): 1221-4.
10. Hebeisen M, Neuenschwander R, Scherer A, Exer P, Weber U, Tamborrini G, et al. Response to tumor necrosis factor inhibition in male and female patients with ankylosing spondylitis: data from a Swiss cohort. J Rheumatol. 2018;45(4):506-12.

11. Lee W, Reveille JD, Davis JC Jr, Learch TJ, Ward $\mathrm{MM}$, Weisman $\mathrm{MH}$. Are there gender differences in severity of ankylosing spondylitis? Results from the PSOAS cohort. Ann Rheum Dis. 2007;66(5):633-8.

12. Baeten D, Sieper J, Braun J, Baraliakos X, Dougados M, Emery P, et al. Secukinumab, an interleukin-17A inhibitor, in ankylosing spondylitis. N Engl J Med. 2015;373(26):2534-48.

13. Feldtkeller E, Lind-Albrecht G. Impact of gender on outcomes in ankylosing spondylitis. Ann Rheum Dis. 2014;73(1): e2-e.

14. Huang F, Sun F, Wan WG, Wu LJ, Dong LL, Zhang $\mathrm{X}$, et al. Secukinumab provided significant and sustained improvement in the signs and symptoms of ankylosing spondylitis: results from the 52-week, Phase III China-centric study, MEASURE 5. Chin Med J. 2020;133(21):2521-31.

15. Kivitz AJ, Wagner U, Dokoupilova E, Supronik J, Martin R, Talloczy Z, et al. Efficacy and safety of secukinumab $150 \mathrm{mg}$ with and without loading regimen in ankylosing spondylitis: 104-week results from MEASURE 4 study. Rheumatol Ther. 2018;5(2):447-62.

16. Glintborg B, Lindstrom U, Di Giuseppe D, et al. Arthritis Care Res (Hoboken). 2020. doi: https://doi. org/10.1002/acr.24523 (Epub ahead of print).

17. Micheroli R, Tellenbach C, Scherer A, Bürki K, Niederman K, Nissen MJ, et al. Effectiveness of secukinumab versus an alternative TNF inhibitor in patients with axial spondyloarthritis previously exposed to TNF inhibitors in the Swiss Clinical Quality Management cohort. Ann Rheum Dis. 2020;79(9):1203-9.

18. Gracey E, Yao Y, Green B, Qaiyum Z, Baglaenko Y, Lin A, et al. Sexual dimorphism in the Th17 signature of ankylosing spondylitis. Arthritis Rheumatol. 2016;68(3):679-89.

19. Giltay EJ, Popp-Snijders C, van Schaardenburg D, Dekker-Saeys BJ, Gooren LJ, Dijkmans BA. Serum testosterone levels are not elevated in patients with ankylosing spondylitis. J Rheumatol. 1998;25(12): 2389-94.

20. Giltay EJ, van Schaardenburg D, Gooren LJ, PoppSnijders C, Dijkmans BA. Androgens and ankylosing spondylitis: a role in the pathogenesis? Ann N Y Acad Sci. 1999;876:340-64 (discussion 65). 
21. Jimenez-Balderas FJ, Tapia-Serrano R, Madero-Cervera JI, Murrieta S, Mintz G. Ovarian function studies in active ankylosing spondylitis in women. Clinical response to estrogen therapy. J Rheumatol. 1990;17(4):497-502.

22. Mahendira D, Thavaneswaran A, Carty A, Haroon $\mathrm{N}$, Anton A, Passalent L, et al. Analysis of the effect of the oral contraceptive pill on clinical outcomes in women with ankylosing spondylitis. J Rheumatol. $2014 ; 41(7): 1344-8$.

23. Lee W, Reveille JD, Weisman MH. Women with ankylosing spondylitis: a review. Arthritis Rheumatol. 2008;59(3):449-54.

24. Fish EN. The X-files in immunity: sex-based differences predispose immune responses. Nat Rev Immunol. 2008;8(9):737-44.

25. Tannenbaum C, Day D. Age and sex in drug development and testing for adults. Pharmacol Res. 2017;121:83-93.

26. Glintborg B, Ostergaard M, Krogh NS, Dreyer L, Kristensen HL, Hetland ML. Predictors of treatment response and drug continuation in 842 patients with ankylosing spondylitis treated with anti-tumour necrosis factor: results from 8 years' surveillance in the Danish nationwide DANBIO registry. Ann Rheum Dis. 2010;69(11):2002-8.

27. Gremese E, Bernardi S, Bonazza S, Nowik M, Peluso G, Massara A, et al. Body weight, gender and response to TNF- $\alpha$ blockers in axial spondyloarthritis. Rheumatology (Oxford). 2014;53(5): 875-81.

28. Gulfe A, Kapetanovic MC, Kristensen LE. Efficacy and drug survival of anti-tumour necrosis factoralpha therapies in patients with non-radiographic axial spondyloarthritis: an observational cohort study from Southern Sweden. Scand J Rheumatol. 2014;43(6):493-7.

29. Haroon N, Inman RD, Learch TJ, Weisman MH, Lee $\mathrm{M}$, Rahbar $\mathrm{MH}$, et al. The impact of tumor necrosis factor $\alpha$ inhibitors on radiographic progression in ankylosing spondylitis. Arthritis Rheumatol. 2013;65(10):2645-54.

30. Kristensen LE, Karlsson JA, Englund M, Petersson IF, Saxne T, Geborek P. Presence of peripheral arthritis and male sex predicting continuation of anti-tumor necrosis factor therapy in ankylosing spondylitis: an observational prospective cohort study from the
South Swedish Arthritis Treatment Group Register. Arthritis Care Res. 2010;62(10):1362-9.

31. Lorenzin M, Ortolan A, Frallonardo P, Oliviero F, Punzi L, Ramonda R. Predictors of response and drug survival in ankylosing spondylitis patients treated with infliximab. BMC Musculoskelet Disord. 2015;16:166.

32. Lubrano E, Perrotta FM, Manara M, D'Angelo S, Addimanda $\mathrm{O}$, Ramonda $\mathrm{R}$, et al. The sex influence on response to tumor necrosis factor- $\alpha$ inhibitors and remission in axial spondyloarthritis. J Rheumatol. 2018;45(2):195-201.

33. Paccou J, Baclé-Boutry MA, Solau-Gervais E, BelePhilippe P, Flipo RM. Dosage adjustment of antitumor necrosis factor- $\alpha$ inhibitor in ankylosing spondylitis is effective in maintaining remission in clinical practice. J Rheumatol. 2012;39(7):1418-23.

34. Pavelka K, Forejtová S, Stolfa J, Chroust K, Buresová L, Mann H, et al. Anti-TNF therapy of ankylosing spondylitis in clinical practice. Results from the Czech national registry ATTRA. Clin Exp Rheumatol. $2009 ; 27(6): 958-63$.

35. Deminger AKE, Geijer M, Göthlin J, Hedberg M, Rehnberg E, et al. A five-year prospective study of spinal radiographic progression and its predictors in men and women with ankylosing spondylitis. Arthritis Res Ther. 2018;20(1):162.

36. Ortolan A, van Lunteren M, Ramiro S, Ramonda R, Landewé RBM, Dagfinrud $\mathrm{H}$, et al. Are genderspecific approaches needed in diagnosing early axial spondyloarthritis? Data from the SPondyloArthritis Caught Early cohort. Arthritis Res Ther. 2018;20(1):218.

37. Webers C, Essers I, Ramiro S, Stolwijk C, Landewé R, van der Heijde D, et al. Gender-attributable differences in outcome of ankylosing spondylitis: longterm results from the Outcome in Ankylosing Spondylitis International Study. Rheumatology (Oxford). 2016;55(3):419-28.

38. Amiri A, Sedighi O. Prevalence of fibromyalgia in patients with ankylosing spondylitis. Med J Dr DY Patil Univ. 2014;7(3):338-41.

39. van der Heijde D, Ramiro S, Landewé R, Baraliakos X, Van den Bosch F, Sepriano A, et al. 2016 update of the ASAS-EULAR management recommendations for axial spondyloarthritis. Ann Rheum Dis. 2017;76(6):978-91. 